\title{
The effect of Cudrania tricuspidata fruit vinegar on LPS-induced inflammation in 3T3-L1 adipocytes
}

\author{
Se-Eun Park ${ }^{1}$, Soo Hwan $\mathrm{Yeo}^{2}$, Seung Kim ${ }^{1 *}$ \\ ${ }^{1}$ Department of Food Science and Biotechnology, Gwangju University, Gwangju 61743, Korea \\ ${ }^{2}$ Fermented Processing Food Science Division, Department of Agrofood Resource, NAS, RDA, Wanju 55365, Korea
}

\section{꾸지뽕 열매 발효식초의 LPS에 의해 유도된 3T3-L1 세포 염증반응 억제 효과}

\author{
박세은 ${ }^{1} \cdot$ 여수환 ${ }^{2} \cdot$ 김승 ${ }^{1 *}$ \\ 1광주대학교 식품생명공학과, ${ }^{2}$ 국립농업과학원 농식품자원부 발효가공식품과
}

\begin{abstract}
Cudrania tricuspidata fruit has anti-inflammatory and anti-obesity effects. The present study aimed to determine the effect of $C$. tricuspidata fruits vinegar (CFV) on lipopolysaccharide (LPS)-induced adipocytes inflammation in 3T3-L1 adipocytes. The differentiation of 3T3-L1 adipocytes was induced by dexamethasone (DEX), 3-isobutyl1-methylxanthine (IBMX) and insulin. Differentiated 3T3-L1 adipocytes were incubated with CFV followed by LPS treatment. The secretion of tumor necrosis factor- $\alpha$ (TNF- $\alpha$ ), interleukin-6 (IL-6) and monocyte chemoattractant protein-1 (MCP-1) were measured using ELISA. The expression of toll-like receptor 4 (TLR4), myeloid differentiation primary response 88 (MyD88), tumor necrosis factor receptor-associated factor 6 (TRAF6) and nuclear factor kappa B (NF-kB) were measured by westem blotting. The results showed that CFV dose-dependently inhibited lipid droplet generation and LPS-induced TNF- 0 , IL-6 and MCP-1 production in the adipocytes. CFV inhibited NF-kB activation, and the LPS-induced expression of TLR4, MyD88, and TRAF6. These results indicated that CFV inhibits the LPS-induced inflammatory response in adipocytes by inhibiting TLR4 signaling, including NF-kB pathways.
\end{abstract}

Key words : Cudrania tricuspidata fruits, vinegar, adipocytes, inflammation, obesity

서 론

비만은 과도한 에너지 섭취로 인해 지방 축적이 과도하게 증 가하고, 지방세포의 크기와 숫자가 비정상적으로 증가하며 발 생하게 된다. 지방 조직은 다양한 아디포카인 및 사이토카인 내 분비에 있어서 중요한 역할을 하며(Castoldi 등, 2016), 지방조 직으로 과도한 에너지 축적은 지방세포의 비대와 이상 증식뿐 만 아니라, leukocytes, granulocytes, monocytes/macrophages, lymphocytes, dendritic cells와 같은 다양한 면역세포의 과도
한 염증인자 생성으로 인해 낮은 수준의 만성적인 염증이 특 징적으로 나타난다(Kalupahana 등, 2012; Rose 등, 2015; Suganami 등, 2017). 지방 조직 내 만성적인 염증은 대식세 포 침윤과 MCP-1, IL-6, IL- $1 \beta, \mathrm{TNF}-\alpha$ 등과 같은 염증성 사 아토카인의 생성이 주된 원인으로 생성된 사이토카인들은 지 방 조직뿐만 아니라 전신성 염증상태를 초래하게 되고, 이는 심혈관계 질환과 당뇨병과 같은 대사성 질환 발생에 밀접한 관련이 있는 것으로 보고되고 있다(De Pergola와 Silvestris, 2013; Suganami 등, 2017; Zhu 등, 2008).

*Corresponding author. E-mail : seungk@gwangju.ac.kr, Phone : +82-62-670-2718, Fax : +82-62-670-2761

Received 14 July 2020; Revised 09 August 2020; Accepted 09 August 2020.

Copyright (c) The Korean Society of Food Preservation.

This is an Open Access article distributed under the terms of the Creative Commons Attribution Non-Commercial License (http://creativecommons.org/licenses/by-nc/4.0) which permits unrestricted non-commercial use, distribution, and reproduction in any medium, provided the original work is properly cited. 
TLRs는 지방세포의 염증반응 유도에서 주된 역할을 하는 수용체로 비만에서 나타나는 만성적인 염증반응에 관여한다. LPS에 의한 TLR4의 발현 증가는 최종적으로 $\mathrm{NF \kappa B}$ 신호 전 달경로를 활성화 시켜 IL-6, TNF- $\alpha$. MCP-1과 같은 염증성 사이토카인들의 발현을 유도하여 지방조직 내로 대식세포의 침윤 유도 및 조직 내 염증반응을 촉진시키며, 비만과 관련되 어 있는 대사성 질환의 발생 기전에서 중요한 역할을 한다 (Suganami 등, 2017; Park과 Mun, 2014).

꾸지뽕(Cudrania tricuspidata)은 뽕나무과의 낙엽교목으 로 한국, 일본, 중국, 러시아 동부지역 등에서 주로 자생한다. 잎은 관절염, 습진, 요통 등의 치료 등의 치료에 사용되었으 며, 열매와 껍질은 중풍, 강장, 이뇨 숙취 해소 등에 사용되어 왔다. 잎과 줄기는 항산화, 항균, 항암, 항당뇨, 간보호 등 다 양한 분야에서 효능 연구가 보고되어 있으며(Kim과 Kim, 2005; Kim 등, 2012; Kim 등, 2008), 열매에 대한 연구는 항 산화, 항염, 면역 증강, 체지방 감소 등에 대해 보고되어 있다 (Joo와 Lim, 2009; Kang 등, 2011; Lee, 2018; Lee 등, 2005; Oh 등, 2009; Park, 2018).

식초는 가장 오래된 조미료로 콜레스테롤 및 체지방 감소, 동맥경화 및 고혈압 예방, 혈당 강하, 면역력 증진, 피로회복 등의 기능성이 있는 것으로 알려져 있다(Petsiou 등, 2014). 식초의 기능성이 주목 받으며 수요가 급증하고 있으며, 다양 한 재료를 활용하여 조미료뿐만 아니라, 기능성 식품으로서 도 활용되고 있다(Nanba와 Kato, 1985). 꾸지뽕 열매에 관한 연구로 지방세포 분화 억제 효과, 콜레스테롤 산화물에 의한 염증 반응 억제 효과에 대해 보고되어 있지만, 비만에 의한 염증 억제 효과에 관한 연구는 미비한 실정이며, 특히 꾸지뽕 열매를 활용한 발효식초에 관한 연구는 거의 없다. 따라서 본 연구에서는 발효과정을 거쳐 제조된 꾸찌뽕 열매 발효식초의 지방세포 내 항염증 활성을 관찰함으로써 비만에 의한 염증 억제를 통한 대사성 질환에 대한 기능성 소재로서의 가능성 을 확인하였다.

\section{재료 및 방법}

\section{실험재료 및 제조}

꾸지뽕 열매는 경남 밀양에서 재배된 것을 구입하였으며, 냉동실에 보관하면서 사용하였다. 냉동상태의 꾸지뽕 열매를 세척하고 꾸지뽕 열매 $1 \mathrm{~kg}$ 을 파쇄한 후 꾸지뽕 원료의 $200 \%(\mathrm{v} / \mathrm{v})$ 를 가수하였다. 꾸지뽕 열매 착즙액에 설탕을 혼합 하여 당도를 $24{ }^{\circ} \mathrm{Brix}$ 로 보정하였다. 꾸지뽕 열매 주스를 $85^{\circ} \mathrm{C}$ 에서 100 분 동안 살균한 후 $25^{\circ} \mathrm{C}$ 로 냉각시키고 Saccharomyces cerevisiae Fermivin(DSM Food Specialties, Delft, Netherlands)를 총량의 $4-6 \%$ 가 되도록 접종하여 $27^{\circ} \mathrm{C}$ 에서 11 일 동
안 발효시켰다. 발효를 통해 얻은 꾸지뽕 열매 와인을 $90^{\circ} \mathrm{C}$ 에 서 40 분 동안 살균한 후 냉각시키고, 초산균(Acetobacter aceti, KCTC, Jeongeup, Korea) 종초를 1:1.2의 부피비로 혼 합하여 $32^{\circ} \mathrm{C}$ 에서 발효시켰다. 발효 7 일 후부터 7 일 간격으로 발효식초에 살균된 꾸지뽕 와인을 유가식으로 첨가하면서 총 21-42일 동안 발효시켜 얻은 발효 식초를 동결건조하여 분말 형태로 만들어 실험에 사용하였다(Baek 등, 2015).

\section{세포배양 및 분화유도}

3T3-L1 세포는 $10 \%$ bovine serum, 100 unit $/ \mathrm{mL}$ penicillin, $100 \mu \mathrm{g} / \mathrm{mL}$ streptomycin이 함유된 Dulbecco's modified Eagle's medium(DMEM, Invitrogen, Carlsbad, CA, USA) 배지를 사용하여 $37^{\circ} \mathrm{C}, 5 \% \mathrm{CO}_{2}$ 조건에서 배양하였다. 6-well plate에 세포를 각 well 당 $3 \times 10^{5}$ cells로 분주한 뒤 세포가 confluent stage에 도달하면 분화 인자 $(0.5 \mathrm{mM}$ IBMX, $2 \mu \mathrm{M}$ $\mathrm{DEX}, 5 \mathrm{mg} / \mathrm{mL}$ insulin)들이 포함된 배지로 교체하여 48시간 동안 지방세포로 분화를 유도하였다. 분화를 유도한 후 5 $\mathrm{mg} / \mathrm{mL}$ insulin이 첨가된 $10 \%$ Fetal bovine serum(FBS)$\mathrm{DMEM}$ 배지로 교체하여 48 시간 동안 배양하였다. $10 \%$ FBS-DMEM 배지로 2 일마다 교체하며 총 4 일간 분화를 유 도하였다. 분화가 완료된 3T3-L1 세포에 $100,150,200 \mu$ $\mathrm{g} / \mathrm{mL}$ 농도의 꾸지뽕 열매 발효식초를 1시간 처리한 후 $\operatorname{LPS}(1 \mu \mathrm{g} / \mathrm{mL})$ 를 24시간 처리하였다.

\section{세포 생존율 측정}

꾸지뽕 열매 발효식초의 세포독성을 3-(4,5-dimethylthiazol2-yl)-2,5-diphenyltetrazolium bromide(MTT) assay을 이용하 여 확인하였다. 3T3-L1 세포를 $1 \times 10^{5}$ cells/well의 농도로 24-well plate에 분주하여 지방세포로 분화시켰다. 분화된 3T3-L1 세포에 발효식초를 24시간 처리하였다. 배지만 처리 한 군을 대조군으로 하였다. 48 시간 후 배지를 제거하고 5 $\mathrm{mg} / \mathrm{mL}$ MTT(최종 농도: $0.5 \mu \mathrm{g} / \mathrm{mL}$ ) 용액을 분주하고 4시간 동안 반응시켰다. 배지를 제거하고 각 well에 생성된 formazan을 dimethly sulfoxide(DMSO) $100 \mu \mathrm{L}$ 를 분주하여 용 해시킨 후, ELISA reader(Molecular Devices, San Jose, CA, USA)를 이용하여 $540 \mathrm{~nm}$ 에서 흡광도를 측정하였다.

\section{Oil Red 0 염색}

6-Well plate에 분주된 3T3-L1 세포를 시료와 함께 분화유 도를 끝낸 후 PBS로 세척하고, $10 \%$ formaldehyde 용액으로 세포를 고정시켰다. 상온에서 1 시간 동안 고정시킨 후 다시 증류수로 세척하고, Oil Red O 염색 시약으로 실온에서 1시 간 염색시켰다. 염색 시약을 제거하고 증류수로 세척한 후 $60 \%$ isopropanol로 염색된 지방구를 용출시켜 ELISA reader 
(Molecular Devices, CA, USA)를 이용하여 $520 \mathrm{~nm}$ 에서 흡 광도를 측정하였다.

\section{ELISA 분석}

배지 내에 생성된 cytokine의 함량은 enzyme-linked immunosorbent assay kits(R\&D Systems, Minneapolis, MN, USA)를 이용하여 제조사에서 제공한 분석방법에 따라 수행 하여 정량하였다.

\section{Western blot 분석}

세포를 phosphate buffered saline(PBS)로 씻어준 후, RIPA buffer $(50 \mathrm{mM}$ Tris-HCl, pH 8.0, $150 \mathrm{mM} \mathrm{NaCl}, 1 \% \mathrm{NP}-40$, $0.5 \%$ Nadeoxycholate, $0.1 \% \mathrm{SDS}$ )에 넣고, 20 분간 $4{ }^{\circ} \mathrm{C}$ 에서 용해시킨 후 $12,000 \mathrm{rpm}, 4^{\circ} \mathrm{C}$ 에서 20 분간 원심분리하여 상등 액만을 취해 단백질을 정량하였다. 단백질 $20 \mu \mathrm{g}$ 에 laemmli sample loading buffer를 가하여, $100^{\circ} \mathrm{C}$ 에서 5 분간 가열하여 변성시킨 단백질을 $12 \%$ acrylamide denaturing SDS polyacrylamide gel에서 전기영동하고, PVDF membrane에 전이시켰다. Membrane을 상온에서 2시간 동안 blocking solution(10 mM Tris, $100 \mathrm{mM} \mathrm{NaCl}, 0.1 \%$ Tween $20,5 \%$ nonfat milk)에 넣고 blocking 시킨 후, 각 단백질에 대한 1차 항체를 희석하여 $4^{\circ} \mathrm{C}$ 에서 하룻밤 동안 반응시켰다. TBST(10 $\mathrm{mM}$ Tris, $100 \mathrm{mM} \mathrm{NaCl}, 0.1 \%$ Tween20) 용액으로 membrane을 3번 씻어준 후, 2차 항체(anti-mouse IgG$\mathrm{HRP} /$ anti-rabbit IgG-HRP)를 희석하여 상온에서 2시간 반응 시켰다. 반응이 끝난 membrane을 3회 씻어준 후 $\mathrm{ECL}$ detection kit(Thermofisher, Waltham, MA, USA)를 이용하 여 발광시킨 membrane을 image reader(Microchemi 4.2, DNR, Neve Yamin, Moshav, IS)로 분석하였다.

\section{통계처리}

모든 실험은 3 회 이상 반복하여 실시하였으며, 실험결과는 평균 \pm 표준편차(SD)로 나타내었으며 통계처리는 SPSS(Statistical Package for Social Science. SPSS Inc., Chicago, IL, USA)를 이용하였다. 각 결과에 대한 유의성 검증은 대조군 과 비교하여 Student's t-test 한 후 ${ }^{* *} \mathrm{p}<0.05,{ }^{*} \mathrm{p}<0.01$ 수준에서 유의성을 검증하였다.

\section{결과 및 고찰}

\section{꾸지뽕 열매 발효식초가 3T3-L1세포의 생존율에 미치는 영향}

지방세포로 분화된 3T3-L1 세포의 세포 생존율에 꾸지뽕 열 매 발효식초가 미치는 영향을 MTT assay를 이용하여 측정하

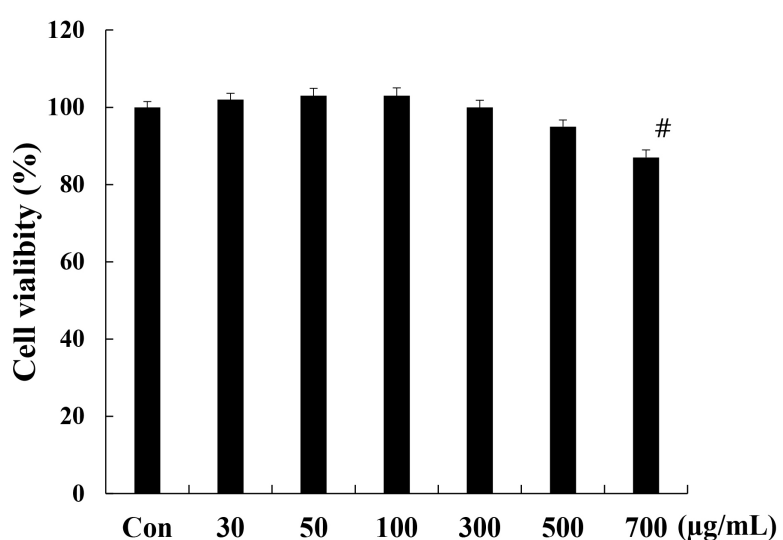

Fig. 1. Effect of Cudrania tricuspidata fruits vinegar (CFV) on viability of differentiated 3T3-L1 cells.

3T3-L1 cells were treated with various concentrations of CFV for 48 h. After incubation, cell viability was assessed using the MTT method. $\#$ p $<0.05$ vs. control group.

였다(Fig. 1). 그 결과, 꾸지뽕 열매 발효식초를 30-700 $\mu \mathrm{g} / \mathrm{mL}$ 농도로 처리하였을 때 $300 \mu \mathrm{g} / \mathrm{mL}$ 이하에서는 세포 생존율이 감소하지 않았지만 $500,700 \mu \mathrm{g} / \mathrm{mL}$ 에서는 세포의 생존율에 감소함을 확인하였다. 따라서 세포 생존율에 영향을 끼치지 않으면서 독성을 나타내지 않는 $300 \mu \mathrm{g} / \mathrm{mL}$ 이하 농도 범위 에서 실험을 진행하였다.

\section{꾸지뽕 열매 발효식초의 lipid droplet 생성억제 효과}

Lipid droplet은 중성지방, perilipin A 등으로 구성되어 있 으며 3T3-L1 지방전구세포에서 지방세포로 분화하는 단계에 서 생성된다. 분화 마지막 단계까지 지속적으로 lipid droplet 를 형성하게 되는데, 시간이 지날수록 lipid droplet들이 결합 하여 그 크기가 점차 증가하게 된다(Brasaemle 등, 2009). 식 초 및 초산류는 체지방 감소 및 콜레스테롤 저하, 항당뇨 등 에 효과가 있어 비만 예방 및 대사증후군과 관련된 질환 예방 에 도움을 주는 것으로 알려져 있다(Petsiou 등, 2014). 꾸지 뽕 열매 발효식초가 3T3-L1 세포의 분화과정에 작용하여 lipid droplet의 생성을 억제하는지 확인하기 위해 분화시키 는 동안 3T3-L1 지방세포에 발효식초 처리한 후 Oil Red O 염색 시약을 이용하여 분화된 지방세포 내에 생성된 lipid droplet을 염색하여 흡광도를 측정하였다(Fig. 2). 그 결과, 꾸 지뽕 열매 발효식초를 처리하지 않고 분화만 유도한 군에서 는 세포 내 lipid droplet의 생성이 현저히 증가하는 것을 확인 하였고, 꾸지뽕 열매 발효식초를 처리하였을 때, 농도의존적 으로 lipid droplet의 생성이 억제되는 것을 확인하였다. 이 결 과에 의해 꾸지뽕 열매 발효식초가 lipid droplet 형성을 저해 시켜 지방 축적 억제 효과가 있는 것으로 사료된다. 


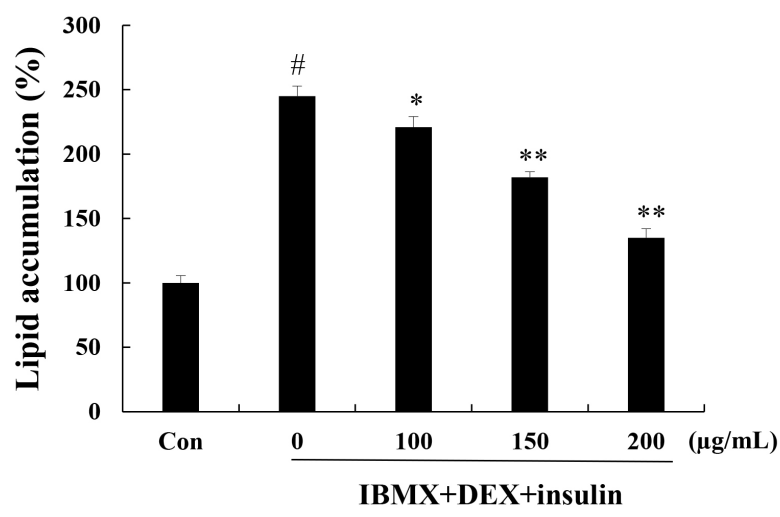

Fig. 2. Effects of Cudrania tricuspidata fruits vinegar (CFV) on the lipid accumulation in 3T3-L1 cells.

The cells were incubated during differentiation with CFV (100, 150, $200 \mu \mathrm{g} / \mathrm{mL}$ ), and lipid accumulation levels were determined by Oil Red $\mathrm{O}$ stain. Oil Red $\mathrm{O}$ dye is dissolved in isopropanol and optical density at $520 \mathrm{~nm}$. The values were calculated as a percentage of absorbance of control. ${ }^{\sharp} p<0.05$ vs. control group; ${ }^{*} p<0.01,{ }^{* *} p<0.05$ vs. IBMX+ $\mathrm{DEX}+$ insulin group.

\section{꾸지뽕 열매 발효식초의 사이토카인 생성억제 효과}

지방조직에서는 염증과 관련된 물질들과 사이토카인들을 분비하며 지방세포와 면역세포 간의 상호작용을 유도하여 염 증반응을 유도하거나 억제시키는 역할을 한다(Chiellini 등, 2002; Park과 Mun, 2014; Suganami 등, 2007). TNF- $\alpha$ 와 IL-6는 지방세포와 대식세포에서 주로 생성되며, 인슐린 저 항성을 증가시키는 주요 인자 중 하나이다(Maachi 등, 2004). $\mathrm{MCP}-1$ 은 지방세포에서 생성되며, 지방조직으로 대식세포의 유입과 인슐린 저항성에서 중요한 역할을 한다(Rull 등, 2010). 비만 발생시 지방조직의 염증성 사이토카인 증가는 비만에 의한 만성적인 염증반응과 당뇨와 같은 대사성 질환 발생의 연결고리가 되고 있다. 본 연구에서는 꾸지뽕 열매 발 효식초의 지방세포 내 항염증 효과를 증명하기 위해, LPS에 의해 염증반응이 유발된 지방세포에서 만성적인 염증에 관여 하는 IL-6, MCP-1, TNF- $\alpha$ 의 생성 억제 여부를 ELISA를 이 용하여 확인하였다(Fig. 3). 그 결과, 대조군에 비해 LPS 만 단독으로 처리한 군의 경우, IL-6, MCP-1, TNF- $\alpha$ 는 생성이 급격하게 증가하였다. 꾸지뽕 열매 발효식초를 전처리한 군
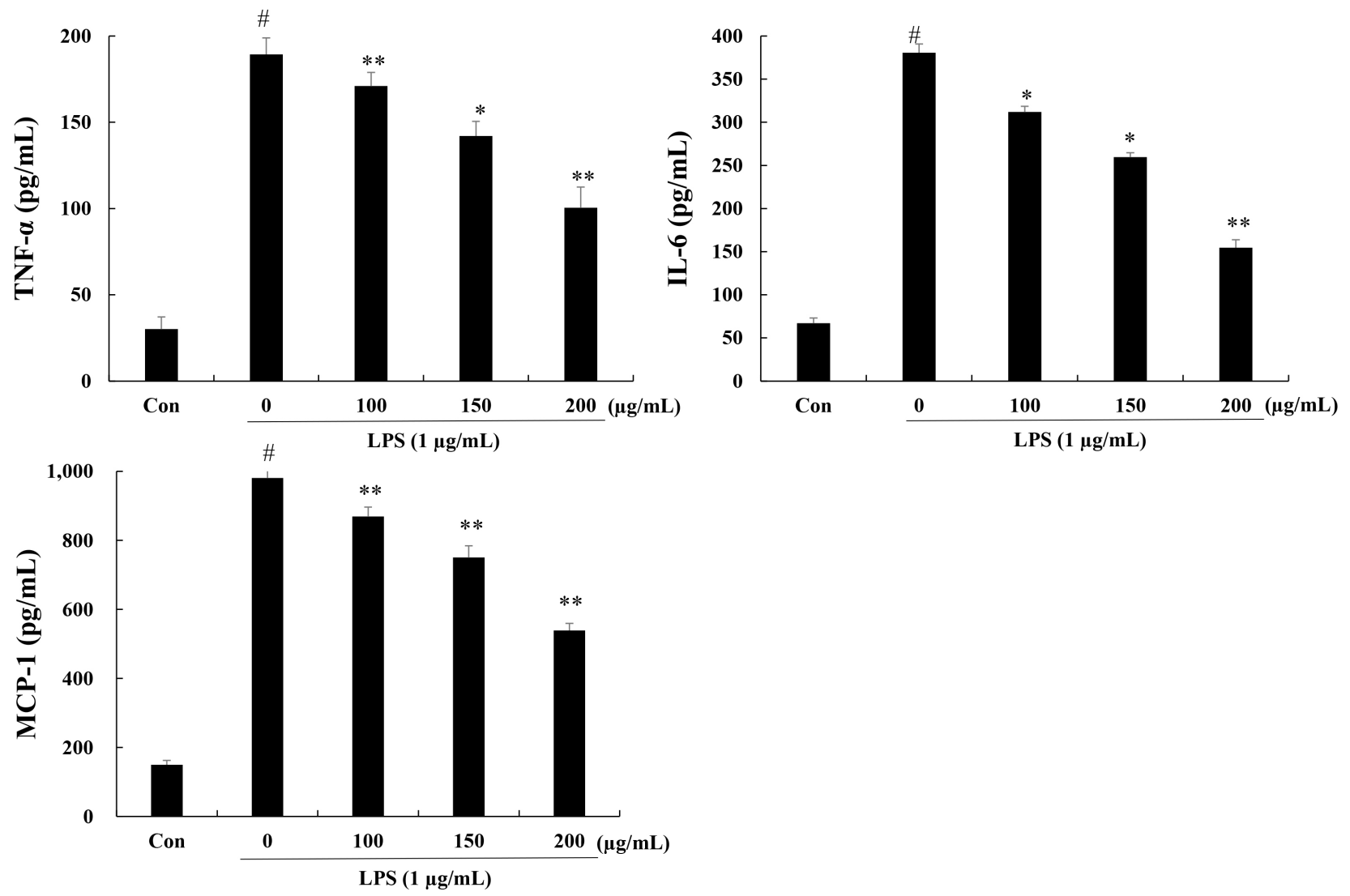

Fig. 3. Effect of Cudrania tricuspidata fruits vinegar (CFV) on LPS-induced TNF- $\alpha$, IL-6 and MCP-1 levels in 3T3-L1 cells.

Differentiated 3T3-L1 cells were pretreated with $(100,150,200 \mu \mathrm{g} / \mathrm{mL})$, for $1 \mathrm{~h}$. Cells were further stimulated with LPS $(1 \mu \mathrm{g} / \mathrm{mL})$. After 24 $\mathrm{h}$, LPS-induced TNF- $\alpha$, IL- 6 and MCP-1 levels were determined by ELISA. ${ }^{\#}<<0.05$ vs. control group; ${ }^{*} \mathrm{p}<0.01,{ }^{* *} \mathrm{p}<0.05$ vs. LPS group. 
에서는 LPS에 의해 유도된 IL-6, MCP-1, TNF- $\alpha$ 의 생성이 농도 의존적으로 감소함을 확인하였다. 이러한 결과들을 통 해서 꾸지뽕 열매 발효식초가 LPS에 의한 IL-6, MCP-1, $\mathrm{TNF}-\alpha$ 의 생성을 억제시킴으로써 3T3-L1 세포의 염증 반응 을 억제시킴을 확인하였다.

\section{꾸지뽕 열매 발효식초의 NF- $K B$ 활성화 억제 효과}

$\mathrm{NF}-\kappa \mathrm{B}$ 는 비만과 연관된 염증 반응에서 염증성 사이토카 인 발현을 조절하는 중요한 전사인자로서 역할을 한다. 일반 적으로 NF- $\mathrm{\kappa B}$ 는 세포질 내에 존재하는 $\mathrm{I} \kappa \mathrm{B}$ 와 결합되어 있지 만(Gloire 등, 2006), LPS로 자극을 받은 지방세포에서는 $\mathrm{NF}-\kappa \mathrm{B}$ p65가 핵 내로 이동하며 MCP-1, IL-6와 같은 염증성 사이토카인의 발현을 유도하며 염증반응을 일으킨다(Chen 등, 2000; Kim과 Kim, 2005).

꾸지뽕 열매 발효식초의 염증성 사이토카인 생성 억제 효 과가 염증반응 신호전달 기전으로 작용하는 NF- $\mathrm{kB}$ 신호전달 과 연관성이 있는지를 확인하기 위해 NF- $\mathrm{kB}$ 와 $\mathrm{I \kappa B}$ 의 활성화

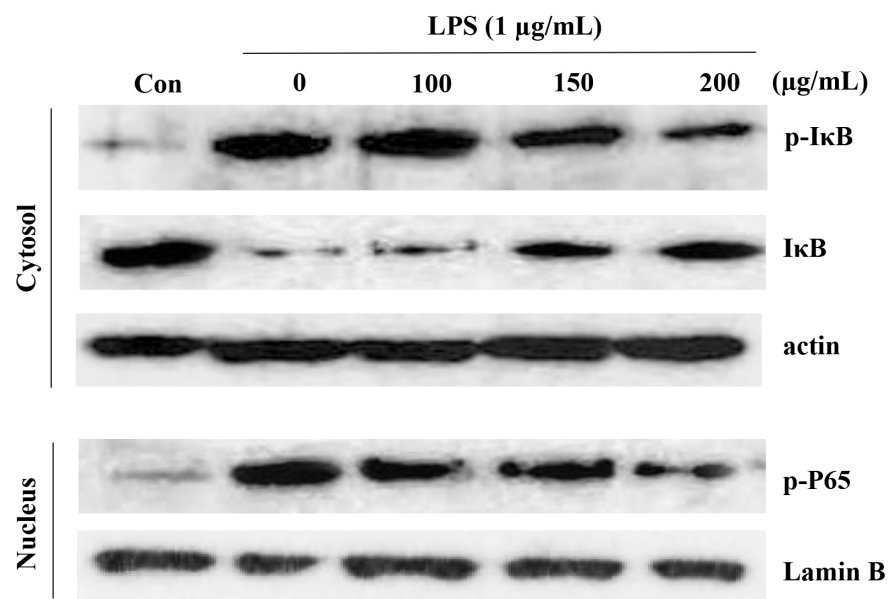

여부를 분석하였다. 꾸지뽕 열매 발효식초의 NF- $\mathrm{KB}$ 활성화 억제 효과를 확인한 결과, LPS에 의해 세포질에서 핵으로 $\mathrm{NF}-\kappa \mathrm{B}$ p65의 현저히 증가됨을 확인하였지만, 꾸지뽕 열매 발효식초를 처리하였을 때 LPS에 의해 유도된 NF- $\mathrm{KB}$ 의 활 성화를 억제시킴을 확인하였다(Fig. 4). 또한, NF- $\mathrm{kB}$ 의 핵 내 전이는 $\mathrm{I \kappa B}$ 의 인산화를 통해 조절되므로 세포질에서 $\mathrm{I \kappa B}$ 의 인산화에 미치는 영향을 확인한 결과, LPS에 의해 유의적으 로 증가한 IKB의 인산화는 꾸지뽕 열매 발효식초에 의해 억제 되는 것으로 나타났다. 따라서, 이러한 결과들은 꾸지뽕 열매 발효식초가 NF-kB의 활성화 억제를 통해서 염증성 사이토카 인인 TNF- $\alpha$, IL-6, MCP-1의 발현을 감소시키며, 이로 인해 LPS에 의한 지방세포의 염증 반응을 억제시킴을 제시한다.

\section{꾸지뽕 열매 발효식초에 의한 TLR4 및 MyD88와 TRAF6 발현 억제 효과}

모든 TLRs 단백질들은 포유동물의 염증반응에 관여하는 것으로 알려져 있다. 사람의 지방조직에서 10 가지의 TLRs가

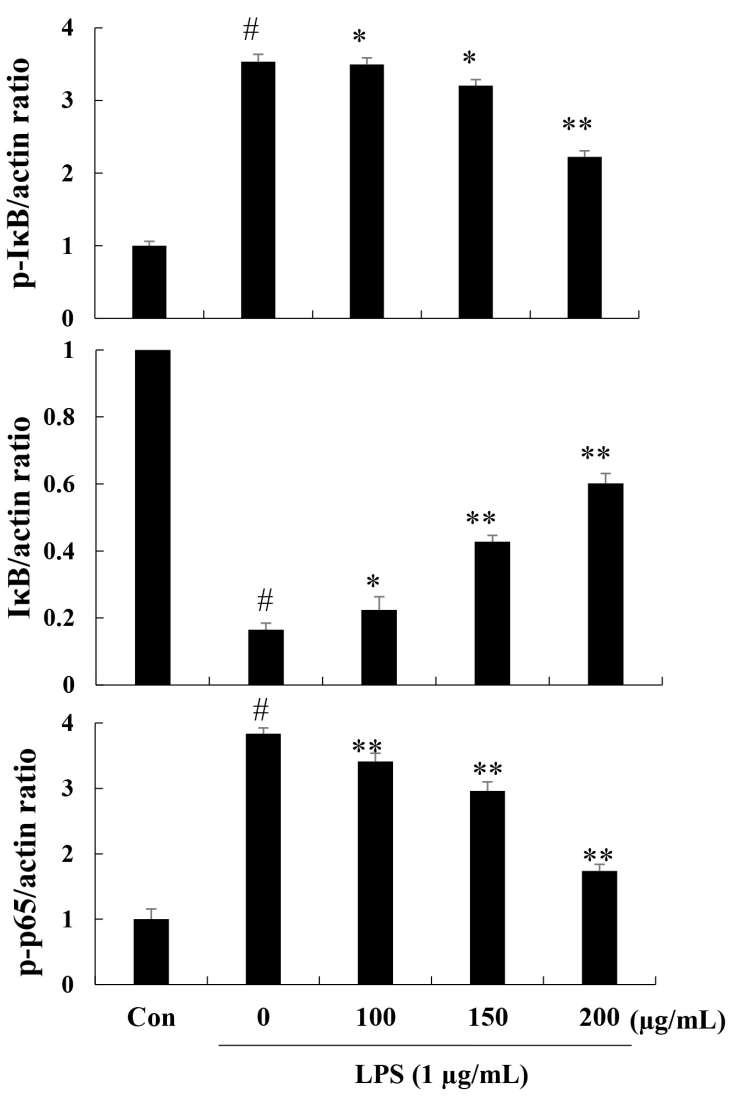

Fig. 4. Effect of Cudrania tricuspidata fruits vinegar (CFV) on LPS-induced NF-кB activation and IkB $\alpha$ degradation in 3T3-L1 cells. Differentiated 3T3-L1 cells were pretreated with CFV $(100,150,200 \mu \mathrm{g} / \mathrm{mL})$, for $1 \mathrm{~h}$. Cells were further stimulated with LPS $(1 \mu \mathrm{g} / \mathrm{mL})$. After $1 \mathrm{~h}$, LPS-induced expression levels were determined western blot. ${ }^{\#}<0.05$ vs. control group; ${ }^{\#} \mathrm{p}<0.05$ vs. control group; ${ }^{*} \mathrm{p}<0.01,{ }^{* *} \mathrm{p}<0.05$ vs. LPS group. 


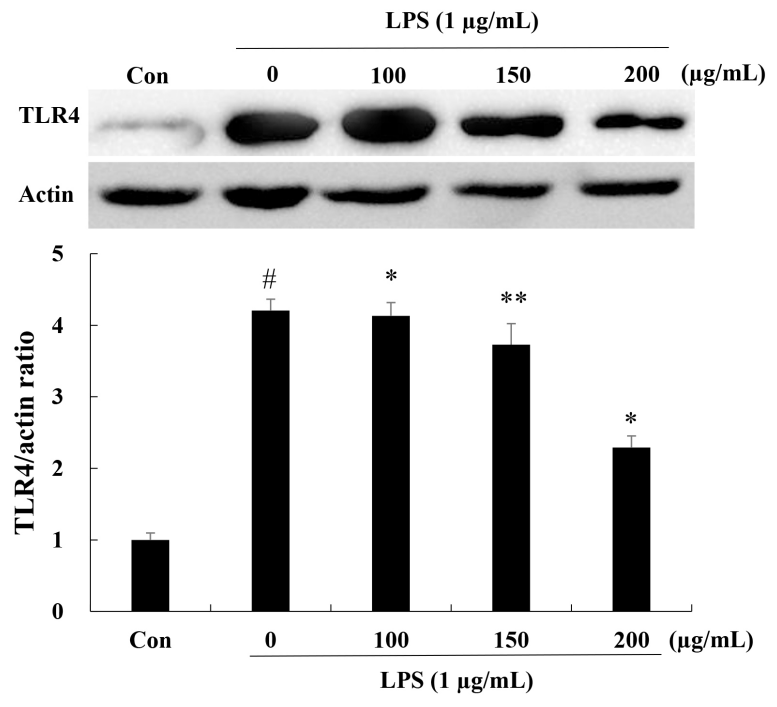

Fig. 5. Effect of Cudrania tricuspidata fruits vinegar (CFV) on LPS-induced expression of TLR4 in 3T3-L1 cells.

Differentiated 3T3-L1 cells were pretreated with CFV (100, 150, 200 $\mu \mathrm{g} / \mathrm{mL})$, for $1 \mathrm{~h}$. Cells were further stimulated with LPS $(1 \mu \mathrm{g} / \mathrm{mL})$ After $1 \mathrm{~h}$, LPS-induced expression levels were determined western blot. ${ }^{*} \mathrm{p}<0.05$ vs. control group; ${ }^{*} \mathrm{p}<0.01,{ }^{* *} \mathrm{p}<0.05$ vs. LPS group.

연구되었으며, 그 중 TLR4는 LPS를 인지하며 염증반응을 유도하는 주된 수용체이다. TLR4 활성화는 MyD88 의존적 신호전달 체계를 통해 이루어지며, 이를 통해 염증반응을 조
절하는 NF-kB를 활성화시킨다(Kawai 등, 1999; Park 등, 2009). 꾸지뽕 열매 발효식초의 TLR4에 미치는 영향을 분석 하기 위해 TLR4의 발현 정도를 확인하였다. 그 결과, TLR4 는 LPS에 의해 자극에 의해 유의적으로 발현량이 증가하였 으며, 꾸지뽕 열매 발효식초에 의해 LPS에 의해 유도된 TLR4 발현을 농도의존적으로 억제하였다(Fig. 5).

MyD88와 TRAF6는 Toll/IL-1 receptor(TIR) domain에 존 재하는 adapter 단백질로 TLR4는 이들 adapter 단백질을 통 해 세포 내로 하부신호전달이 이루어지게 된다. 이러한 신호 전달을 통해 NF- $\kappa \mathrm{B}$ 가 활성화되어 염증성 사이토카인의 발현 이 증가하게 된다(Chen 등, 2000). 꾸지뽕 발효식초에 의한 TLR4 발현 억제가 MyD88와 TRAF6 발현에 영향을 미치는 지 여부를 확인하였다(Fig. 6). 그 결과, LPS로 염증반응이 유 도된 3T3-L1 세포에서 MyD88과 TRAF6 모두 대조군에 비 해 발현량이 급격하게 증가하여 이들이 활성화되었음을 확인 하였으며, 반대로 꾸지뽕 열매 발효식초를 처리한 군에서는 발현을 농도의존적으로 억제하였다.

TLR4는 LPS를 인지하는 주된 수용체로 TLR4의 신호전 달은 NF- $\mathrm{NB}$ 경로를 따라 활성화되어 염증반응을 유도하게 된다(Arko-Mensah 등, 2007). TLR의 신호전달은 MyD88 의 존 유무에 따라 신호전달 기작이 나뉘고, 그에 따라 다른 기 작이 활성화 된다. MyD88 의존적인 경우에는 TRAF6가 활 성화 되고 TRAF6는 NF- $\kappa \mathrm{B}$ 를 활성화시켜 염증성 사이토카
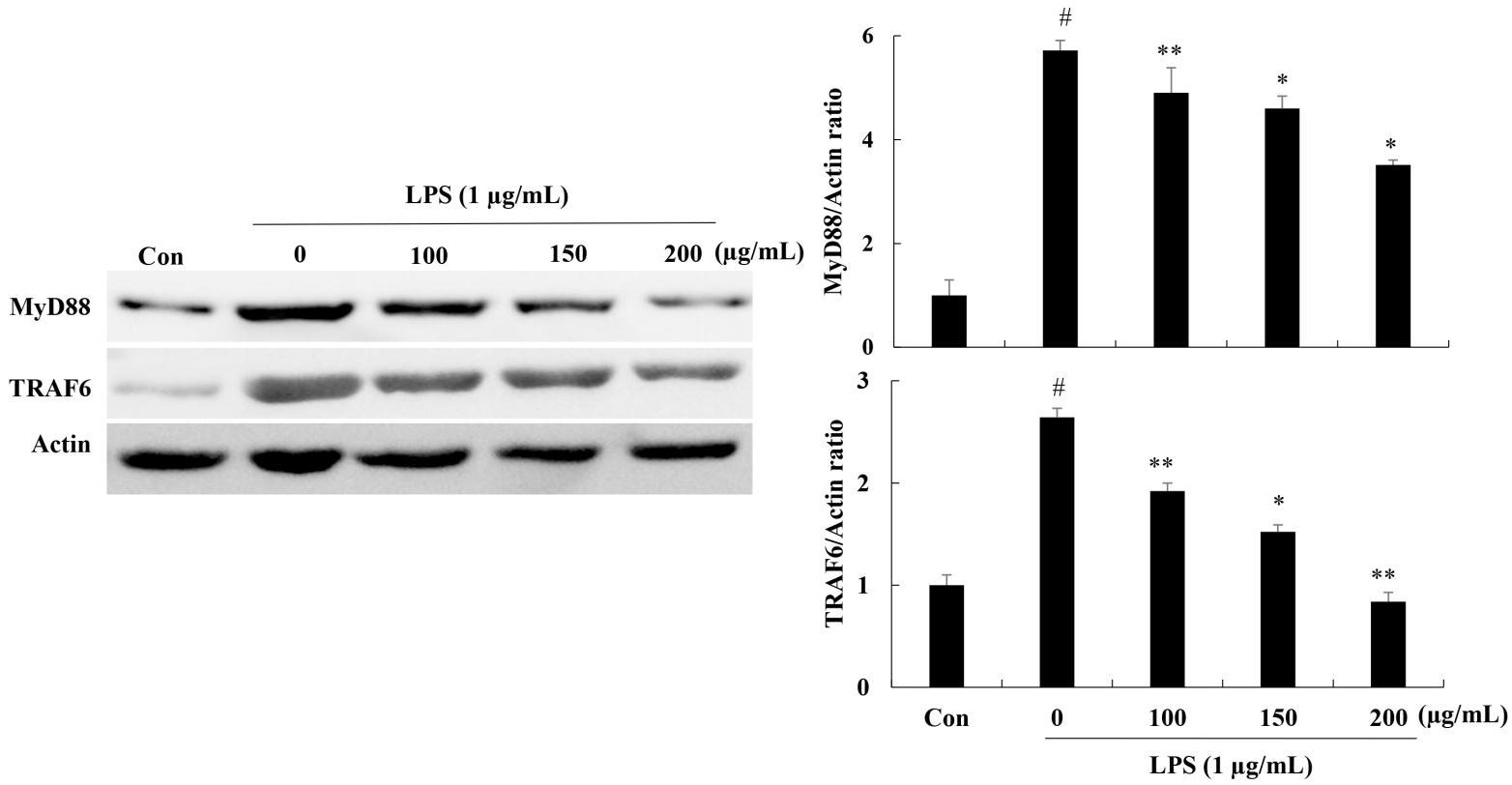

Fig. 6. Effect of Cudrania tricuspidata fruits vinegar (CFV) on LPS-induced expression of MyD88 and TRAF in 3T3-L1 cells.

Differentiated 3T3-L1 cells were pretreated with CFV $(100,150,200 \mu \mathrm{g} / \mathrm{mL})$, for $1 \mathrm{~h}$. Cells were further stimulated with LPS $(1 \mu \mathrm{g} / \mathrm{mL})$. After $1 \mathrm{~h}$, LPS-induced expression levels were determined western blot. ${ }^{\#}<0.05$ vs. control group; ${ }^{*} \mathrm{p}<0.01,{ }^{* *} \mathrm{p}<0.05$ vs. LPS group. 
인의 생성을 유도한다. 꾸지뽕 열매 발효식초가 LPS에 의해 유도된 TLR4 및 MyD88와 TRAF6 발현을 억제시킴을 확인 하였고, 이러한 연구결과는 꾸지뽕 열매 발효식초가 TLR4의 $\mathrm{MyD} 88$ 의존적 신호전달 경로 억제를 통해서 항염증 활성을 조절함을 제시하고 있다.

본 연구를 통해서 꾸지뽕 열매 발효식초의 지방세포 내의 lipid droplet 생성을 억제하였으며, LPS에 의해 염증반응이 유도된 지방세포의 MyD88 의존적 TLR4-NF- $\mathrm{kB}$ 경로 억제 를 통해서 염증성 사이토카인 발현을 저해하는 것을 확인하 였다. 그러므로 이상의 결과들은, 꾸지뽕 열매 발효식초의 지 방 축적 억제 및 염증 반응 억제 효과를 통해서 비만에 의한 대사성 질환과 염증 억제에 대한 기능성 소재로서의 활성 가 능성을 제시하고 있다.

\section{요 약}

본 연구는 LPS에 의해 유도된 3T3-L1 세포의 염증 반응에 서 꾸지뽕(C. tricuspidata) 열매 발효식초의 억제 효과를 연 구하였다. 분화유도인자(IBMX, DEX, insulin) 처리에 의해 분화된 지방세포에 꾸지뽕 열매 발효식초를 전처리한 후 LPS를 처리하였다. 꾸지뽕 열매 발효 식초는 LPS에 의해 염 증반응이 유발된 분화된 지방세포에서 염증성 사이토카인 (TNF- $\alpha$, IL-6 MCP-1)의 생성을 감소시켰으며, 염증 반응에 있어 주요한 인자인 TLR, MyD88, TRAF의 발현 억제와 $\mathrm{NF}-\kappa \mathrm{B}$ 활성화을 억제시킴을 확인하였다. 또한 3T3-L1 세포 내의 lipid droplet의 생성을 억제하였다. 이러한 결과들을 통 해 꾸지뽕 열매 발효식초는 NF-kB를 포함하는 TLR4 경로 억제를 통해 염증성 사이토카인의 생성을 저해함으로써 지방 세포 내에서 항염증 효과 및 지방 축적 억제 효과를 보여주고 있어 비만에 의한 염증 억제와 대사성 질환을 예방할 수 있는 기능성 소재로서 이용 가능할 것으로 사료된다

\section{감사의 글}

본 연구는 2020년도 농촌진흥청 연구사업(과제번호: PJ 012588032020)의 지원에 의해 수행되었습니다.

\section{Conflict of interests}

The authors declare no potential conflict of interest.

\section{ORCID}

Se-Eun Park https://orcid.org/0000-0001-6644-3080
Seung Kim https://orcid.org/0000-0001-6249-8156

\section{References}

Arko-Mensah J, Julian E, Singh M, Fernandez C. TLR2 but not TLR4 signalling is critically involved in the inhibition of IFN- $\gamma$-induced killing of mycobacteria by murine macrophages. Scand J immunol, 65, 148-157 (2007)

Baek SY, Lee CH, Park YK, Choi HS, Mun JY, Yeo SH. Quality characteristics of fermented vinegar prepared with the detoxified Rhus verniciflua extract. Korean J Food Preserv, 22, 674-682 (2015)

Brasaemle DL, Subramanian V, Garcia A, Marcinkiewicz A, Rothenberg A. Perilipin A and the control of triacylglycerol metabolism. Mol Cell Biochem, 326, 15-21 (2009)

Castoldi A, Naffah de Souza C, Camara NOS, MoraesVieira PM. The macrophage switch in obesity development. Front Immunol, 6, 637 (2016)

Chen Y, Yang L, Lee TJ. Oroxylin A inhibition of lipopolysaccharide-induced iNOS and COX-2 gene expression via suppression of nuclear factor- $\kappa \mathrm{B}$ activation. Biochem Pharmacol, 59, 1445-1457 (2000)

Chiellini C, Bertacca A, Novelli SE, Gorgun CZ, Ciccarone A, Giordano A, Xu H, Soukas A, Costa M, Gandini D, Dimitri R, Bottone P, Cecchetti P, Pardini E, Perego L, Navalesi R, Folli F, Benzi L, Cinti S, Friedman JM, Hotamisligil GS, Maffei M. Obesity modulates the expression of haptoglobin in the white adipose tissue via TNF $\alpha$. J Cell Physiol, 190, 251-258 (2002)

De Pergola G, Silvestris F. Obesity as a major risk factor for cancer. J Obes, 29156 (2013)

Gloire G, Legrand-Poels S, Piette J. NF- $\kappa$ B activation by reactive oxygen species: Fifteen years later. Biochem Pharmacol, 72, 1493-1505 (2006)

Joo HY, Lim KT. Glycoprotein isolated from Cudrania tricuspidata Bureau inhibits $\mathrm{iNO}$ and COX-2 expression through modulation of NF- $\kappa B$ in LPS-stimulated RAW 264.7 cells. Environ Toxicol Pharmacol, 27, 247-252 (2009)

Kalupahana NS, Moustaid-Moussa N, Claycombe KJ. Immunity as a link between obesity and insulin resistance. Mol Aspects Med, 33, 26-34 (2012) 
Kang DH, Kim JW, Youn KS. Antioxidant activities of extracts from fermented Mulberry (Cudrania tricuspidata) fruit, and inhibitory actions on elastase and tyrosinase. Korean J Food Preserv, 18, 236-243 (2011)

Kawai T, Adachi O, Ogawa T, Takeda K, Akira S. Unresponsiveness of MyD88-deficient mice to endotoxin. Immunity, 11, 115-122 (1999)

Kim JW, Kim C. Inhibition of LPS-induced NO production by taurine chloramine in macrophages is mediated though Ras-ERK-NF- $\kappa$ B. Biochem Pharmacol, 70, 1352- 1360 (2005)

Kim OK, Ho JN, Nam DE, Jun WJ, Hwang KT, Kang JE, Chae OS, Lee JM. Hepatoprotective effect of Curdrania tricuspidata extracts against oxidative damage. J Korean Soc Food Sci Nutr, 41, 7-13 (2012)

Kim YC, Hur J, Sohn DH, Kim HS. Antibacterial compounds of the root Barks of Cudrania tricuspidata. Kor J Pharmacogn, 39, 246-248 (2008)

Lee BW, Lee JH, Lee ST, Lee HS, Lee WS, Jeong TS, Park $\mathrm{KH}$. Antioxidant and cytotoxic activities of xanthones from Cudrania tricuspidata. Bioorg Med Chem Lett, 15, 5548-5552 (2005)

Lee JA. Investigation of anti-inflammatory effects of 4'O-methylalpinum isoflavone on 27-hydroxycholesterolinduced inflammation. MS Thesis. Pusan National University, Korea, p 4 (2018)

Maachi M, Pieroni L, Bruckert E, Jardel C, Fellahi S, Hainque B, Capeau J, Bastard JP. Systemic low-grade inflammation is related to both circulating and adipose tissue TNF $\alpha$, leptin and IL-6 levels in obese women. Int J Obes, 28, 993-997 (2004)

Nanba T, Kato H. Applications of mirin and non-salt soy bean miso to vinegar brewing. Nippon Shokuhin Kogyo Gakkaishi, 32, 731-737 (1985)

Oh PS, Lee HJ, Lim KT. Inhibitory effect of glycoprotein isolated from Cudrania tricuspidata Bureau on histamine release and COX-2 activity in RBL-2H3 cells. Korean J Food Sci Technol, 41, 405-412 (2009)

Park BS, Song DH, Kim HM, Choi BS, Lee H, Lee JO. The structural basis of lipopolysaccharide recognition by the TLR4-MD-2 complex. Nature, 458, 1191-1195 (2009)

Park JK. Antithrombotic and antiadipogenic effects of Cudrania tricuspidata fruit extract. Ph D Thesis, Kyung Hee University, Korea, p 69-75 (2018)

Park MY, Mun ST. Carnosic acid inhibits TLR4-MyD88 signaling pathway in LPS-stimulated 3T3-L1 adipocytes. Nutr Res Pract, 8, 516-520 (2014)

Petsiou EI, Mitrou PI, Raptis SA, Dimitriadis GD. Effect and mechanisms of action of vinegar on glucose metabolism, lipid profile, and body weight. Nutr Rev, 72, 651-661 (2014)

Rose DP, Gracheck PJ, Vona-Davis L. The interactions of obesity, inflammation and insulin resistance in breast cancer. Cancers, 7, 2147-2168 (2015)

Rull A, Camps J, Alonso-Villaverde C, Joven J. Insulin resistance, inflammation, and obesity: role of monocyte chemoattractant protein-1 (orCCL2) in the regulation of metabolism. Mediators Inflammation, 2010, 326580 (2010)

Suganami T, Tanimoto-Koyama K, Nishida J, Itoh M, Yuan X, Mizuarai S, Kotani H, Yamaoka S, Miyake K, Aoe S, Kamei Y, Ogawa Y. Role of the toll-like receptor $4 / \mathrm{NF}-\kappa \mathrm{B}$ pathway in saturated fatty acid-induced inflammatory changes in the interaction between adipocytes and macrophages. Arterioscler Thromb Vasc Biol, 27, 84-91 (2007)

Zhu J, Yong W, Wu X, Yu Y, lv J, Liu C, Mao X, Zhu $\mathrm{Y}, \mathrm{Xu} \mathrm{K}$, Han X, Liu C. Anti-inflammatory effect of resveratrol on TNF- $\alpha$-induced MCP-1 expression in adipocytes. Biochem Biophys Res Commun, 369, 471477 (2008) 